\title{
EMPLOYEE TRUST AS A MEDIATION THAT AFFECTS PERFORMANCE :STUDY IN REGIONAL SECRETARIAT OF WEST ACEH
}

\author{
Putra Rinanda ,Nasir and Sofyan \\ Department of Management, Universities Syiah Kuala, Indonesia
}

http://doi.org/10.35409/IJBMER.2019.2424

\begin{abstract}
The purpose of this study is to test the effect of knowledge management and emotional intelligence on employee trust and their simultaneous impact on organizational performance. The population in this study is all employees of the Regional Secretariat of the West Aceh, which amounted to 148 people. Sampling technique used is the census method that is taken the entire population as a sample, so there are as much as 148 respondents. The result figures that knowledge management effects the employee trust significantly, emotional intelligence effects the employee trust significantly, knowledge management effects organizational performance significantly, emotional intelligence effects organizational performance significantly, employees trust effects organizational performance significantly, knowledge management effects organizational performance through employee trust significantly, and emotional intelligence effects organizational performance through employee trust significantly. These all findings both direct effects or indirect effects can be a strong reference for academic area. The originality lies in the integration of the causality theories from the several previous research, and its timeline and object. So that the model in this research can also be a basic to develop another model in further. For practical persons, this is useful for the managers/leaders especially in the Regional Secretariat of West Aceh
\end{abstract}

Keyword: Knowledge Management, Emotional Intelligence, Employee Trust, Organizational Performance.

\section{INTRODUCTION}

Organizational performance has not met expectations could be caused by a lack of trust among employees. (Fadli Yunadi, Hafasnuddin, 2017). Trust employees or employee trust is part of gaining knowledge in an organization primarily gained knowledge of co-workers. Knowledge in the organization is spread through the sharing of knowledge or often referred to knowledge sharing. Knowledge can be shared and exchanged verbally through these activities, but sometimes less optimal for employee participation are not fully engaged. Employee participation is driven by their cooperative relationship is affected by Employee confidence or trust in which the Employee with colleagues can trust or not. Trust form the basis of effective communication,

Employees will be selective for the exchange of knowledge with co-workers, when an employee does not trust his colleagues then the process can not be maximized. Knowledge 


\section{International Journal of Business Management and Economic Review}

Vol. 2, No. 06; 2019

ISSN: 2581-4664

Management are trying to gather knowledge about the procedure of maintaining an organization compiled by each individual for later coalesced into the organized collective knowledge. (Azhari, Musnadi and Tabrani, 2017). But if the set of knowledge is not shared to other employees because of the element of distrust, it will decrease the performance of the organization. While emotional intelligence (emotional quotient, abbreviated as EQ) is the ability to receive, assess, manage, and control the emotions himself and others around him. The higher the emotional intelligence course increased the probability to be able to have confidence in co-workers so that will have a positive impact in improving the performance of its organization. But unfortunately this mechanism that has not been seen in the organization of the District Secretariat of West Aceh.

\section{LITERATURE REVIEW Organizational performance}

The concept of performance can be defined as the level of achievement of results. Performance is the result of a series of processes activities undertaken to achieve specific goals of an organization. According (Thoyibatun, 2012) performance is often interpreted as performances, demonstrations or achievements. Performance is the rate of continuous phase to organizational goals, while according to (Ahdiyana, 2009) performance is an overview of the level of program implementation achievement, activity or policy in achieving the goals, objectives, vision and mission as stated in the strategic planning of an organization. The concept of organizational performance also illustrates that each public organization provides services to the community and can measure its performance by using existing performance indicators to see whether the organization has carried out its duties properly and to find out its objectives have been achieved or not. (Yunadi, Hafasnuddin and Ridwan, 2017)

\section{Employee trust}

The definition of trust and commitment is a belief that the statement of the other party can be relied upon to fulfill its obligations (Koesmono, 2007). Sense of trust or not to trust someone who appears in behavior is determined by factors such as information, influence and control. Confidence will rise when information received rated accurate, relevant, and complete. the level of trust is also influenced by past experience, a positive experience that is consistent in the past with a party will increase mutual trust that will raise hopes of a good relationship in the future (Siti Hajar, 2018). The level of trust is also influenced by past experiences, positive experiences that are consistent in the past with a party will increase mutual trust so that it will foster hope for a good relationship in the future. (Hajar, Lubis and Lubis, 2018)

\section{Knowledge management}

Knowledge management is the process whereby an organization collects knowledge assets (knowledge assets) and use it to gain competitive advantage. (Kosasih and Budiani, 2008). With the development of knowledge, Employees will know or understand what is needed to be able to do his job well. When organizations make a huge investment to businesses gather knowledge assets (knowledge assets), then the organization should be able to know how big the impact of the implementation of knowledge management to organizational performance and confident that what the organization in order to gather knowledge assets is in line with the vision 


\section{International Journal of Business Management and Economic Review}

Vol. 2, No. 06; 2019

ISSN: 2581-4664

and mission of the organization. This knowledge management can also be interpreted as how much employee understanding of the basic principles of management are suspected as a major component to achieve a smooth process or collective activity that exists in an organization. (Azhari, Musnadi and Tabrani, 2017)

\section{Emotional intelligence}

Emotional intelligence is a skill in managing emotions that provides the ability to balance it in order to maximize long-term happiness in life. (Thaib, 2013). Emotional intelligence is very important for the person because humans are creatures of emotion. (Mahdani, Hafasnuddin and Adam, 2017). Often times a person makes a decision based on all day with no logic but carried away by feelings or emotions. People who have low emotional intelligence will oscillate with a feeling of uncertainty, so it is difficult to make quick decisions (Yantiek, 2014). Sering kali seseorang membuat keputusan seharian dengan tidak berlandaskan logika tetapi karena terbawa oleh perasaan atau emosi diri. Mahdani, F., Hafasnuddin \& Adam, M. (2017).

\section{Research paradigm and Hypothesis}

From the description above, the paradigm of this research and the hypothesis can be figured as follows.

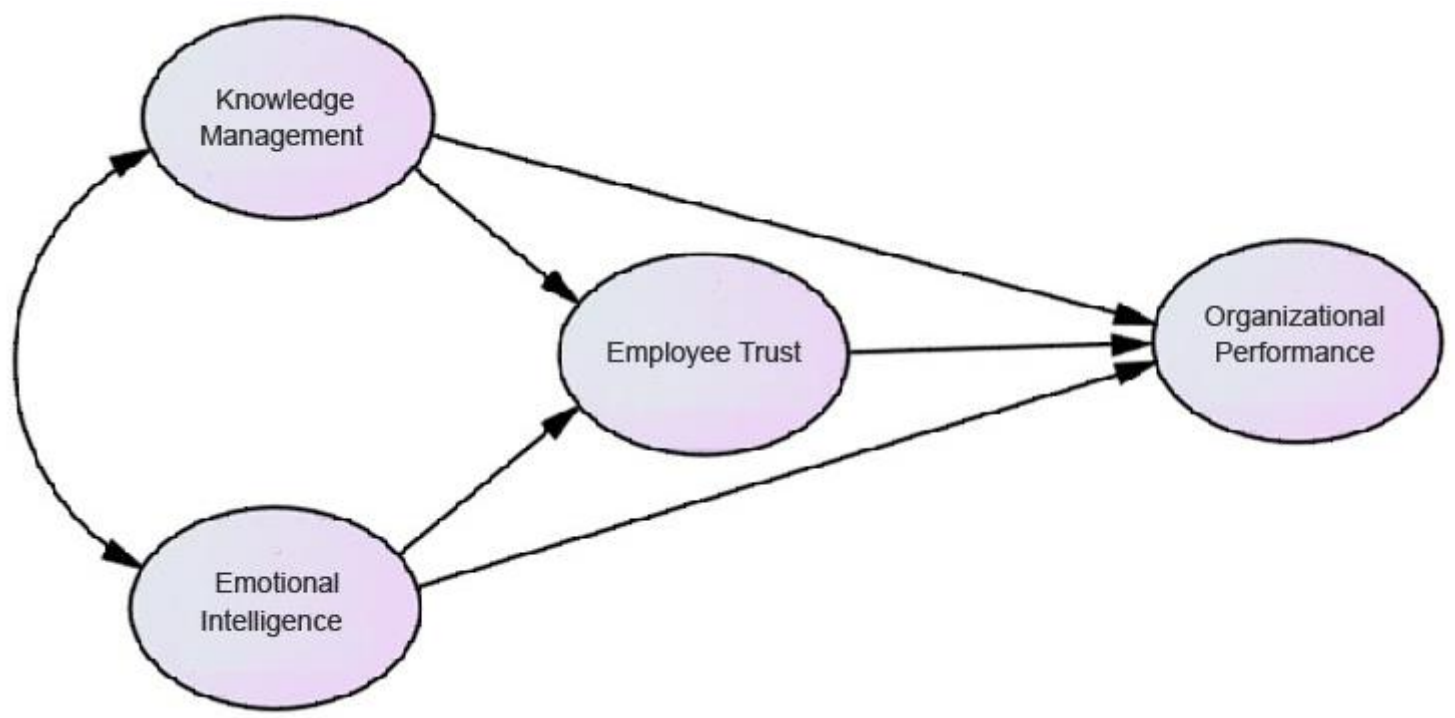

Figure 1. Research paradigm

H1 : knowledge management effects the employee trust significantly.

$\mathrm{H} 2$ : emotional intelligence effects the employee trust significantly

H3: knowledge management effects organizational performance significantly

H4 : emotional intelligence effects organizational performance significantly

H5 : employees trust effects organizational performance significantly

H6: knowledge management effects organizational performance through employee trust significantly

H7: emotional intelligence effects organizational performance through employee trust significantly 


\section{International Journal of Business Management and Economic Review}

Vol. 2, No. 06; 2019

ISSN: 2581-4664

\section{RESEARCH METHOD}

This study is conducted at the regional secretariat of west aceh, indonesia. the variables are the knowledge management, emotional intelligence, employee trust and organizational performance. The authors build constructs to measure the variables, that are : 1) for knowledge management : 1. personal knowledge, 2. job procedure , 3. technology for sharing, 4. willingness to share, 5. willingness to accept; 2) for emotional intelligence : 1 . know self emotions, 2. manage emotions, 3. self motivation, 4. empathy; 3) for employee trust : 1. maintain relationships, 2. receive influence, 3. open in communication, 4. reducing supervision, and 5. patience will understand; and 4) for organizational performance : 1. input, 2. output, 3. outcome, 4. benefit, 5 . impact.

The population is all civil servants in the Regional Secretariat of West Aceh, amounting to 148 people. The sampling technique used is a census. This means that all populations are to serve as the respondent that as many as 148 people. Processing of the data obtained in the field is conducted by using a model equation is anlisa ststistik multivariate techniques to be able to analyze not only the influence of variables, but also the relationship with the indicator variables respectively. Ha acceptance criteria is Critical Ratio $(\mathrm{CR})>1.96$ and the Probability $(\mathrm{P})<0.05$.

Also, in testing the significance of indirect effects the calculation uses the Sobel Test by comparing the value of the sobel statistics with a cut-off of 1.96 or comparing the value its $p$ value with a cut-off value of 0.05 . It is said that the indirect effect is significant if the value of sobel $>1.96$ or $\mathrm{p}<0.05$.

\section{RESULTS}

Testing the validity of the loading factor can be seen in the image and the following table:

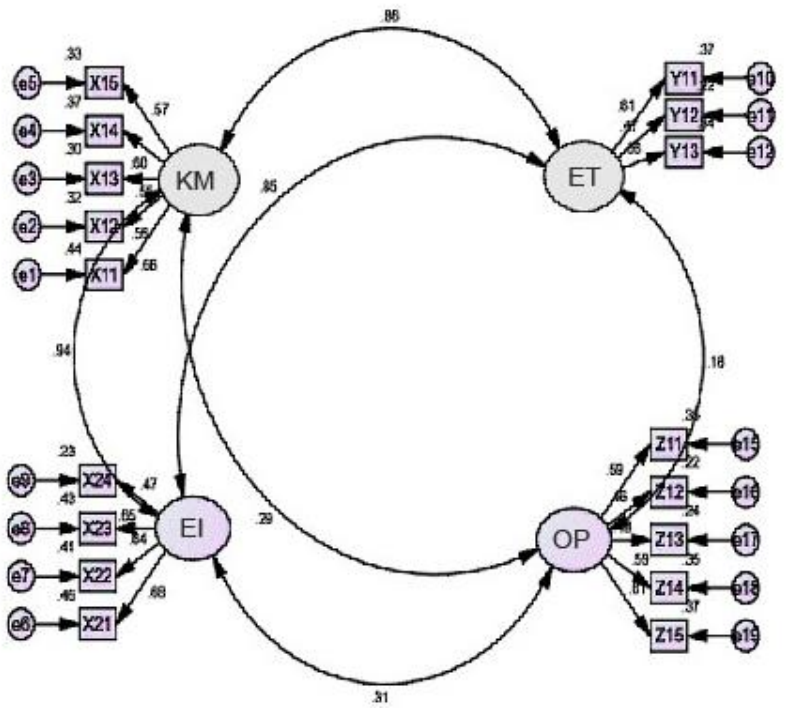

Figure 2. Loading Factor 


\section{International Journal of Business Management and Economic Review}

Vol. 2, No. 06; 2019

ISSN: 2581-4664

The test results show that some indicators of measurement of the variables have values below the loading factor of 0.5 , that are in employee trust variable, so the indicators are not used. The following table of net measurement test results that can later be included in the structural testing.

Table 1. Loading Factor

\begin{tabular}{|l|l|l|l|l|}
\hline No. & Indicator & & variables & estimate \\
\hline 1 & X11 & $<---$ & KM & .664 \\
\hline 2 & X12 & $<---$ & KM & .562 \\
\hline 3 & X13 & $<---$ & KM & .545 \\
\hline 4 & X14 & $<---$ & KM & .604 \\
\hline 5 & X15 & $<---$ & KM & .571 \\
\hline 6 & X21 & $<---$ & EI & .679 \\
\hline 7 & X22 & $<---$ & EI & .638 \\
\hline 8 & X23 & $<---$ & EI & .652 \\
\hline 9 & X24 & $<---$ & EI & .475 \\
\hline 10 & Y11 & $<---$ & ET & .612 \\
\hline 11 & Y12 & $<---$ & ET & .471 \\
\hline 12 & Y13 & $<---$ & ET & .583 \\
\hline 13 & Z11 & $<---$ & OP & .593 \\
\hline 14 & Z12 & $<---$ & OP & .464 \\
\hline 15 & Z13 & $<---$ & OP & .485 \\
\hline 16 & Z14 & $<---$ & OP & .589 \\
\hline 17 & Z15 & $<---$ & OP & .609 \\
\hline
\end{tabular}

Table 1 shows the loading factor of all indicators in the model, and already qualify for further treatment because it has a loading factor> 0.5 .

Table 2. Goodness of Fit

\begin{tabular}{|l|l|l|l|}
\hline $\begin{array}{l}\text { Criteria Index } \\
\text { Size }\end{array}$ & Cut-off Value & Results Analysis & evaluation Model \\
\hline Chi Square & $\begin{array}{l}\text { expected to be } \\
\text { small }\end{array}$ & 137781 & Fit \\
\hline CMIN / DF & CMIN / DF $<2$ & 1,219 & Fit \\
\hline GFI & $\geq 0.90$ & 0.904 & Fit \\
\hline AGFI & $\geq 0.90$ & 0.869 & Well \\
\hline
\end{tabular}


International Journal of Business Management and Economic Review

Vol. 2, No. 06; 2019

ISSN: 2581-4664

\begin{tabular}{|l|l|l|l|}
\hline \hline $\begin{array}{l}\text { Criteria Index } \\
\text { Size }\end{array}$ & Cut-off Value & Results Analysis & evaluation Model \\
\hline IFI & $\geq 0.90$ & 0.955 & Well \\
\hline CFI & approaching 1 & CFI Above 0.5 & relatively Good \\
\hline PNFI & $0-1$ & PNFI 0-1 & Fit \\
\hline RMSEA & $<0.08$ & 0039 & Fit \\
\hline
\end{tabular}

Structural testing conducted has produced the information needed to answer the hypotheses that have been built before whether proven or not. Figure 3 below illustrates the effect of variables:

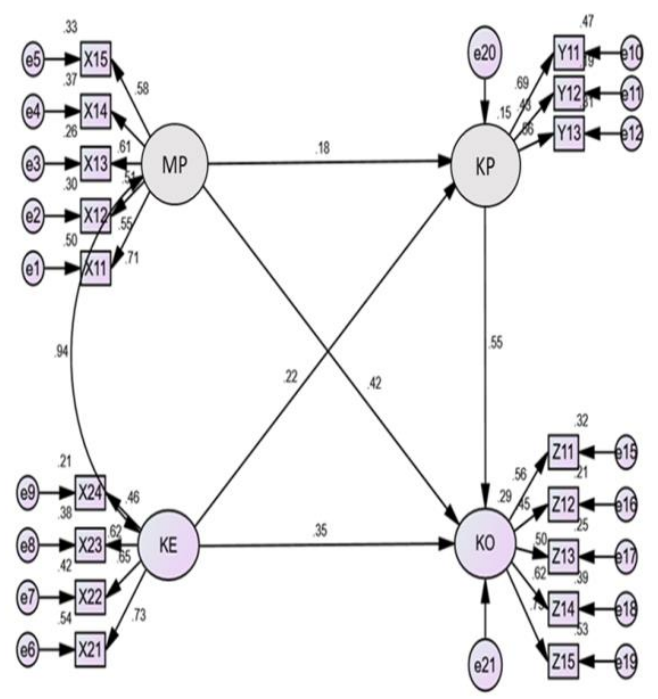

Figure 3. Structural Equation Model

Based on Figure 3 can be explained the influence of each variable is Transformational Leadership Style, Organizational Commitment, Sustainable Work Engagement and Employee Performance.

Whole picture of hypothesis testing along with the results shown in Table 3 below:

Table 3. Conclusion of direct effect hypothesis

\begin{tabular}{|l|l|l|l|l|}
\hline No. & hypothesis & $\begin{array}{l}\text { CR Cut } \\
\text { Off }>\end{array}$ & $\begin{array}{l}\text { P Value } \\
\text { Cut off } \\
<\mathbf{0 . 0 5}\end{array}$ & $\begin{array}{l}\text { Informati } \\
\text { on }\end{array}$ \\
\hline 1 & Knowledge Management $\rightarrow$ Employee Trust & 5,007 & $* * *$ & H1 \\
\hline
\end{tabular}




\section{International Journal of Business Management and Economic Review}

Vol. 2, No. 06; 2019

ISSN: 2581-4664

\begin{tabular}{|c|c|c|c|c|}
\hline No. & hypothesis & $\begin{array}{lr}\text { CR } & \text { Cut } \\
\text { Off r } & > \\
1.96 & \\
\end{array}$ & $\begin{array}{l}\text { P Value } \\
\text { Cut off } \\
<0.05\end{array}$ & $\begin{array}{l}\text { Informati } \\
\text { on }\end{array}$ \\
\hline & & & & Accepted \\
\hline 2 & Emotional Intelligence $\rightarrow$ Employee Trust & 4,947 & $* * *$ & $\begin{array}{l}\mathrm{H} 2 \\
\text { Accepted }\end{array}$ \\
\hline 3 & 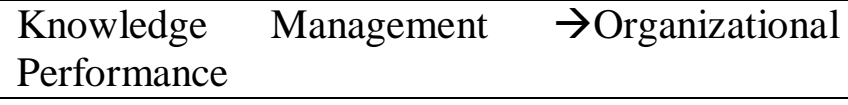 & 2,217 & $* * *$ & $\begin{array}{l}\mathrm{H} 3 \\
\text { Accepted }\end{array}$ \\
\hline 4 & $\begin{array}{l}\text { Employee confidence } \rightarrow \text { Organizational } \\
\text { Performance }\end{array}$ & 5693 &, 012 & $\begin{array}{l}\mathrm{H} 4 \\
\text { Accepted }\end{array}$ \\
\hline 5 & 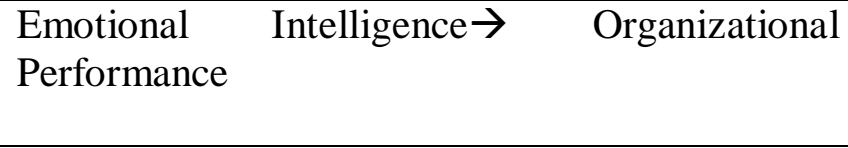 & 2,207 & $* * *$ & $\begin{array}{l}\text { H5 } \\
\text { Accepted }\end{array}$ \\
\hline
\end{tabular}

From table 3 describes the 5 direct hypotheses are accepted. In other words that the other exogen variables namely Knowledge Management and Emotional Intelligence has the effect to increase the endogen variables that are employee trust and organizational performance.

The following is the conclusion of the that indirect effect hypotheses that are the Knowledge Management and Emotional Intelligence on Organizational Performance in the Regional Secretariat of West Aceh district through Employee Trust

Table 4. Conclusion Hypothesis Indirect

\begin{tabular}{|c|c|c|c|c|c|c|c|}
\hline No. & Hypothesis & & & $\begin{array}{l}\mathrm{P} \\
\text { Value } \\
<0.05\end{array}$ & Beta & $\begin{array}{l}\text { Informatio } \\
\mathrm{n}\end{array}$ & $\begin{array}{l}\text { Mediation } \\
\text { role }\end{array}$ \\
\hline 1 & $\begin{array}{l}\text { knowledge } \\
\text { organizational } \\
\text { employee trust }\end{array}$ & $\begin{array}{l}\text { management } \\
\text { performance }\end{array}$ & $\begin{array}{l}\text { effects } \\
\text { through }\end{array}$ & 0.000 & $\begin{array}{l}0.09 \\
5\end{array}$ & accepted & $\begin{array}{l}\text { Partial } \\
\text { mediating }\end{array}$ \\
\hline 2 & $\begin{array}{l}\text { Emotional } \\
\text { organizational } \\
\text { employee trust }\end{array}$ & $\begin{array}{l}\text { intelligence } \\
\text { performance }\end{array}$ & $\begin{array}{l}\text { effects } \\
\text { through }\end{array}$ & 0.000 & .117 & accepted & $\begin{array}{l}\text { Partial } \\
\text { mediating }\end{array}$ \\
\hline
\end{tabular}

The Table 4 is the results that using Sobel test as a test calculation for indirect effect. The results have proven that:

1) Knowledge management effects on organizational performance through employee trust significantly. It is explained by the value of two tailed $\mathrm{p}$ sobel $=0.000<0.05$ shows that the indirect effect is significant. Because both directly and through employee trust the influence of knowledge management on organizational performance is significant, the role of employee trust variables here is partial mediaton;

2) Emotional intelligence effects organizational performance through employee trust significantly. It can be seen that the $\mathrm{p}$ value of two tailed sobel test $=0,000<0.05$, it is proven 


\section{International Journal of Business Management and Economic Review}

Vol. 2, No. 06; 2019

ISSN: 2581-4664

that the indirect effect is significant. Because both directly and through employee confidence the influence of emotional intelligence on organizational performance is significant, so in this case employee confidence has a partial mediation role.

From the findings of this study, it is proven that the employee trust variable has the largest beta coefficient which can be described as the biggest trigger in boosting organizational performance. Than the main finding is the employee trust is as a partial mediation role in this research model.

\section{CONCLUSIONS}

The result figures that knowledge management effects the employee trust significantly, emotional intelligence effects the employee trust significantly, knowledge management effects organizational performance significantly, emotional intelligence effects organizational performance significantly, employees trust effects organizational performance significantly, knowledge management effects organizational performance through employee trust significantly, and emotional intelligence effects organizational performance through employee trust significantly. These all findings both direct effects or indirect effects can be a strong reference for academic area. The originality lies in the integration of the causality theories from the several previous research, and its timeline and object. So that the model in this research can also be a basic to develop another model in further. For practical persons, this is useful for the managers/leaders especially in the Regional Secretariat of West Aceh. Partial mediating role also makes it as an important component in improving organizational performance so this employee trust variable needs more attention to be maintained. The indicator variables that have the lowest value in employee trust is openness in communication between employers and employees.

\section{REFERENCES}

Ahdiyana, M. (2009) 'Memperkuat Manajemen Strategis Dengan Pengukuran Kinerja Dalam Organisasi Sektor Publik', Universitas Negeri Yogyakarta, pp. 1-14. doi: 10.1200/JCO.2008.17.2015.

Azhari, Musnadi, S. and Tabrani, M. (2017) 'Pengaruh Manajemen Pengetahuan, Gaya Kepemimpinan Dan Insentif Terhadap Kinerja Pegawai Serta Implikasinya Terhadap Kinerja Organisasi Pada Kantor Pelayanan Pajak Pratama Banda Aceh', Jurnal Manajemen dan Inovasi, 8(2), pp. 1-14.

Fadli Yunadi, Hafasnuddin, R. I. (2017) 'Pengaruh Lingkungan Kerja, Motivasi, Masalah Personal, Dan Pelatihan Terhadap Kinerja Karyawan Serta Dampaknya Terhadap Kinerja Organisasi RSUD Meuraxa Kota Banda Aceh', Jurnal Manajemen Dan Inovasi, 8(3), pp. $37-51$.

Hajar, S., Lubis, A. R. and Lubis, P. H. (2018) 'Pengaruh Perilaku Kepemimpinan Dan Kepercayaan Terhadap Kinerja Dinas Sosial Tenaga Kerja Dan Transmigrasi Kabupaten Aceh Barat', Jurnal Magister Manajemen, 2(1), pp. 46-57.

Koesmono, H. T. (2007) 'Pengaruh Kepemimpinan Dan Tuntutan Tugas Terhadap Komitmen Organisasi Dengan Variabel Moderasi Motivasi Perawat Rumah Sakit Swasta Surabaya', Jurnal Manajemen dan Kewirausahaan, 9(1), pp. 30-40. doi: 10.9744/jmk.9.1.pp.30-40.

Kosasih, N. and Budiani, S. (2008) 'Pengaruh Knowledge Management Terhadap Kinerja Karyawan: Studi Kasus Departemen Front Office Surabaya Plaza Hotel', Jurnal 


\section{International Journal of Business Management and Economic Review}

Vol. 2, No. 06; 2019

ISSN: 2581-4664

Manajemen Perhotelan, 3(2), pp. 80-88. doi: 10.9744/jmp.3.2.80-88.

Mahdani, F., Hafasnuddin and Adam, M. (2017) 'Serta Implikasinya Pada Kinerja Karyawan ( Studi Pada Kanwil Pt . Bank Rakyat Indonesia (Persero) Tbk. Banda Aceh', Jurnal Magister Manajemen, 1(1), pp. 1-15.

Siti Hajar, A. R. L. P. H. L. (2018) 'Pengaruh Perilaku Kepemimpinan Dan Kepercayaan Terhadap Kinerja Dinas Sosial Tenaga Kerja Dan Transmigrasi Kabupaten Aceh Barat', Jurnal Magister Manajemen, 2(1), pp. 46-57.

Thaib, E. N. (2013) 'Hubungan Antara Prestasi Belajar Dengan Kecerdasan Emosional', Jurnal Ilmiah Didaktika, 13(2), pp. 384-399. doi: 10.22373/jid.v13i2.485.

Thoyibatun, S. (2012) 'Faktor-Faktor Yang Berpengaruh Terhadap Perilaku Tidak Etis Dan Kecenderungan Kecurangan Akuntansi Serta Akibatnya Terhadap Kinerja Organisasi', EKUITAS (Jurnal Ekonomi dan Keuangan), 16(2), pp. 245-260.

Yantiek, E. (2014) 'Kecerdasan Emosi, Kecerdasan Spiritual dan Perilaku Prososial Remaja', Persona:Jurnal Psikologi Indonesia, 3(01), pp. 22-31. doi: 10.30996/persona.v3i01.366.

Yunadi, F., Hafasnuddin and Ridwan (2017) 'Pengaruh Lingkungan Kerja, Motivasi, Masalah Personal, Dan Pelatihan Terhadap Kinerja Karyawan Serta Dampaknya Terhadap Kinerja Organisasi', Jurnal Manajemen dan Inovasi, 8(3). 